\title{
Perbandingan Pengaruh Indeks Massa Tubuh (IMT) Perokok dengan Bukan Perokok Pasien Penyakit Jantung di Rumah Sakit Umum Daerah Kota Bekasi Tahun 2016
}

\section{Comparison of body mass index effect of smoker and non-smoker patients with heart patient in RSUD Bekasi City in 2016}

\author{
Santi Dwi Rahmawati ${ }^{1}$, Kenconoviyati ${ }^{2}$ \\ ${ }^{1}$ Fakultas Kedokteran Universitas YARSI, Jakarta \\ ${ }^{2}$ Departemen Pendidikan Fakultas Kedokteran Universitas YARSI, Jakarta \\ Koresponden E-mail: kenconoviyati.yarsi.ac.id
}

\begin{abstract}
Abstrak
Indeks massa tubuh (IMT) adalah berat badan dalam kilogram $(\mathrm{kg})$ dibagi tinggi badan dalam meter kuadrat $\left(\mathrm{m}^{2}\right)$ Indeks massa tubuh merupakan suatu parameter obesitas yang dapat memperkirakan risiko seseorang dapat terkena penyakit penyerta obesitas atau tidak. Makin tinggi nilai IMT, makin tinggi pula risiko terkena penyakit penyerta obesitas. Indeks massa tubuh berlebih atau obesitas mengundang potensi terserang penyakit diabetes dan hipertensi yang nantinya juga akan berdampak pada jantung. Tujuan penelitian ini adalah mengetahui perbandingan pengaruh indeks massa tubuh perokok dengan bukan perokok pasien penyakit jantung di RSUD Kota Bekasi Penelitian ini menggunakan desain penelitian cross sectional dengan jenis data kuantitatif. Teknik penetapan besar sampel dilakukan dengan menggunakan rumus Slovin. Total responden penelitian sebanyak 160 responden, dengan kriteria yaitu pasien yang berkunjung dan berobat ke poli jantung RSUD Kota Bekasi pada tahun 2016. Pengambilan data menggunakan kuesioner dengan analisa statistika Chi-square. Hasil analisis uji statistik chi-square didapatkan indeks massa tubuh pasien perokok penyakit jantung memiliki $p$-value $<0.03$ yang dikatakan terdapat hubungan antara indeks masa tubuh perokok dengan penyakit jantung. Berbanding terbalik dengan pasien bukan perokok yang memiliki $p$-value $>0,05$ dikatakan tidak terdapat hubungan antara indeks massa tubuh dengan penyakit jantung. Indeks massa tubuh perokok pasien penyakit jantung lebih banyak memiliki indeks massa tubuh yang lebih. Sedangkan untuk bukan perokok lebih banyak memiliki indeks massa tubuh normal
\end{abstract}

Kata Kunci : Indeks Massa Tubuh, Merokok, Penyakit jantung

\section{Abstrct}

Body mass index is an obesity parameter that can estimate a person's risk of being obese or no obese. Excess body mass index or obesity invite potential for diabetes and hypertension that will give impact for the heart. This aim of study to know the comparison of the effect of body mass index of 
smokers with non-smokers of heart disease patients in RSUD Bekasi city and views according to islam.This research used cross sectional research design with quantitative data types. Total respondents of the study are 160 respondents, with the criteria of patients visited and treatment to the heart of hospital RSUD Bekasi city in 2016. The research used questionnaires with chi-square statistical analysis to collect the data. Body mass index of smoker heart disease patient has $p$-value $<0.03$, there is relation between body mass index of smoker with heart disease, in contrast to nonsmoker patients ( $p$-value $<0.05)$ that is no relationship between body mass index and heart disease. The body mass index of smokers of heart disease patients has more body mass index where as for non-smokers more have a normal body mass index.

Keywords : Body mass Index, Smoker, Heart Disease

\section{Pendahuluan}

Indeks massa tubuh (IMT) adalah berat badan dalam kilogram $(\mathrm{kg})$ dibagi tinggi dalam meter kuadrat $\left(\mathrm{m}^{2}\right)$ (Sugondo, 2006). IMT merupakan indikator yang paling sering digunakan dan praktis untuk mengukur tingkat populasi berat badan lebih dan obese pada orang dewasa. Indeks massa tubuh merupakan suatu parameter obesitas yang bisa memperkirakan risiko seseorang dapat terkena penyakit penyerta obesitas atau tidak. Makin tinggi nilai IMT, makin tinggi pula risiko terkena penyakit penyerta obesitas (Damanik, 2009).

Merokok merupakan faktor risiko mayor untuk terjadinya penyakit jantung, termasuk serangan jantung dan stroke, dan juga memiliki hubungan kuat untuk terjadinya PJK sehingga dengan berhenti merokok akan mengurangi risiko terjadinya serangan jantung (T.F.M Van Berkel.1999). Menurut Davidson et al (1988) perokok adalah yang telah merokok 1 batang atau lebih tiap hari sekurang-kurangnya selama 1 tahun, jika selama 1 bulan meninggalkan rokok (tidak merokok) disebut sebagai riwayat perokok. Jika selama 5 tahun berhenti merokok maka di sebut sebagai mantan perokok (leffondre et al,
2002). Kebiasaan merokok merupakan faktor resiko paling banyak di temukan di Indonesia yang menyebabkan terjadinya penyakit jantung koroner. Dengan menghentikan kebiasaan merokok dapat mengurangi kejadian penyakit jantung koroner pertama maupun selanjutnya, serta sangat cost effective (Septawati, 2009).

Berdasarkan WHO (2011) bahwa penyakit jantung merupakan penyebab kematian nomor satu di dunia dan $60 \%$ dari seluruh penyebab kematian penyakit jantung adalah penyakit jantung iskemik dan sedikitnya 17,5 juta atau setara dengan 30,0\% kematian di seluruh dunia disebabkan oleh penyakit jantung. Faktor Risiko jenis kelamin, wanita mempunyai faktor resiko terkena serangan penyakit jantung lebih rendah dari pada pria. Penyakit jantung koroner jarang terjadi pada wanita premenopause, kecuali terdapat faktor risiko ganda. Terdapat kekecualian pada wanita dengan penyakit Diabetes mellitus dan Obesitas. Kadar kolesterol tinggi merupakan faktor utama penyakit jantung koroner dan Hipertensi termasuk salah satu faktor resikonya (Septawati, 2009).

Dari hasil penelitian sebelumnya bahwa terdapat antara berat badan dengan penyakit 
jantung koroner dan adanya kelebihan berat badan yang diakibatkan oleh penimbunan lemak tubuh yang berlebih, Penimbunan lemak yang berlebih pada dasarnya akan mempengaruhi penyakit pasien jantung koroner dan merokok merupakan salah satu faktor risiko mayor timbulnya aterosklerosis.

\section{Bahan dan Metoda Penelitian}

Jenis penelitian ini merupakan penelitian komparatif deksriptif. Rancangan penelitian ini menggunakan desain penelitian cross sectional. Pemilihan sampel menggunakan metode Sampling Kuota dengan cara penetapan sampel menggunakan rumus Slovin. Sampel yang diambil adalah pasien penyakit jantung di RSUD kota bekasi tahun 2016. Jenis data yang digunakan adalah data kuantitatif yang diperoleh dengan cara membagikan kuesioner kepada Pasien penyakit jantung yang berkunjung ke RSUD kota Bekasi tahun 2016. Analisa data yang digunakan adalah analisa chi-square.

\section{Hasil Penelitian}

Setelah dilakukan penetapan besar sampel menggunakan Sampling Kuota, diperoleh jumlah responden sebesar 78 pasien jantung bukan perokok dan 82 pasien jantung perokok. Responden akhir yang digunakan dalam penelitian adalah 160 responden.

Table 4.1. Menunjukan karakteristik responden pasien penyakit jantung di RSUD kota bekasi dari jumlah sampel 160 pasien penyakit jantung, proporsi responden memiliki jenis kelamin laki-laki yang lebih besar yaitu sebanyak 81 pasien atau sebesar 52.6\%. Sementara sebanyak 73 pasien atau sebesar $47.4 \%$ berjenis kelamin perempuan.

Kemudian dari tabel juga diperoleh, pasien yang memiliki usia 21-30 tahun sebanyak 1 pasien (0.6\%); pasien yang memiliki usia 31-40 tahun sebanyak 5 pasien (3.1\%); pasien yang memiliki usia 41-50 tahun sebanyak 20 pasien (12.5\%); pasien yang memiliki usia 51-60 tahun sebanyak 72 pasien (45\%); pasien yang memiliki usia 61-70 tahun sebanyak 49 pasien (30.6\%); dan untuk pasien yang memiliki usia 71-80 tahun sebanyak 13 pasien (8.1\%); Hal ini menunjukkan bahwa pasien penyakit jantung yang menjadi sampel dalam penelitian ini berdasarkan karakteristik usia didominasi oleh pasien yang memiliki jenis kelamin laki-laki sedangkan berdasarkan karakteristik usia didominasi oleh pasien yang memiliki usia 51 60 Tahun.

Table 4.1. Karakteristik Responden

\begin{tabular}{cccc}
\hline Karakteristik & & Frekuensi & $\%$ \\
\hline Jenis Kelamin & Laki-laki & 81 & $50.6 \%$ \\
& Perempuan & 79 & $49.3 \%$ \\
\hline Usia & 21-30 Tahun & 1 & $0.6 \%$ \\
& 31-40 Tahun & 5 & $3.1 \%$ \\
& 41-50 Tahun & 20 & $12.5 \%$ \\
& 51-60 Tahun & 72 & $45 \%$ \\
& 61-70 Tahun & 49 & $30.6 \%$ \\
& 71-80 Tahun & 13 & $8.1 \%$ \\
\hline
\end{tabular}


Table 4.2. Kuisioner Responden

\begin{tabular}{lccc}
\hline \multicolumn{1}{c}{ Karakteristik } & & Perokok & Bukan Perokok \\
\hline Sampai Saat ini Masih Merokok & Ya & 20 & 0 \\
& Tidak & 57 & 77 \\
Jumlah Batang Rokok yang & O Batang & 57 & 77 \\
Dihabiskan & 10 Batang & 16 & 0 \\
BB mempengaruhi Penyakit & $>10$ Batang & 4 & 0 \\
& Ya & 20 & 18 \\
Gaya Hidup Mempengaruhi BB & Tidak & 57 & 59 \\
Kegiatan Sehari-hari Mempengaruhi & Ya & 33 & 25 \\
Penyakit & Tidak & 44 & 52 \\
Kadar Kolesterol & Ya & 51 & 33 \\
& Tidak & 26 & 44 \\
Faktor Lain & Normal & 35 & 16 \\
& Tidak Normal & 18 & 21 \\
& Tidak Tahu & 24 & 40 \\
& Hipertensi & 20 & 18 \\
& Diabetes Melitus & 3 & 3 \\
& Kolesterol & 19 & 21 \\
\hline
\end{tabular}

Tabel. 4.3. Indeks Massa Tubuh Responden dan Penyakit Jantung

\begin{tabular}{|c|c|c|c|c|c|c|}
\hline PEROKOK & $\begin{array}{l}\text { Berat } \\
\text { badan } \\
\text { kurang }\end{array}$ & $\begin{array}{l}\text { Berat } \\
\text { badan } \\
\text { normal }\end{array}$ & $\begin{array}{l}\text { Kelebihan } \\
\text { berat } \\
\text { badan }\end{array}$ & $\begin{array}{l}\text { Beresiko } \\
\text { menjadi } \\
\text { obesitas }\end{array}$ & $\begin{array}{l}\text { Obesitas } \\
1\end{array}$ & $\begin{array}{l}\text { Obesitas } \\
2\end{array}$ \\
\hline Penyakit jantung koroner & 1 & 10 & 1 & 12 & 14 & 1 \\
\hline Gagal jantung kongestive & & 3 & 2 & 2 & 10 & 2 \\
\hline Defek septum atrium & - & - & - & - & - & 1 \\
\hline Pembengkakan & 1 & - & - & - & 1 & 1 \\
\hline Kelainan jantung & 1 & - & - & - & - & - \\
\hline Penyakit iskemik kronis & - & 1 & - & - & - & - \\
\hline Jantung & - & & - & - & 2 & - \\
\hline Pengentalan darah & - & 1 & - & - & - & - \\
\hline Bengkak katup jantung & - & - & - & - & - & 1 \\
\hline
\end{tabular}




\begin{tabular}{lcccccc}
\hline BUKAN PEROKOK & $\begin{array}{l}\text { Berat } \\
\text { badan } \\
\text { kurang }\end{array}$ & $\begin{array}{l}\text { Berat } \\
\text { badan } \\
\text { normal }\end{array}$ & $\begin{array}{l}\text { Kelebihan } \\
\text { berat } \\
\text { badan }\end{array}$ & $\begin{array}{l}\text { Beresiko } \\
\text { menjadi } \\
\text { obesitas }\end{array}$ & $\begin{array}{c}\text { Obesitas 1 } \\
\text { Obesitas }\end{array}$ \\
\hline Penyakit jantung koroner & 2 & 8 & 5 & 10 & 12 & 6 \\
Gagal jantung kongestive & 1 & 4 & 3 & 1 & 4 & 1 \\
Defek septum atrium & - & - & 1 & - & - & - \\
Pembengkakan & - & 1 & - & - & - & 3 \\
Kelainan jantung & - & - & - & 1 & - & - \\
Bocor katup jantung & - & 2 & - & 1 & 1 & - \\
Lemah jantung & - & - & - & 1 & - & - \\
\hline
\end{tabular}

\section{Diskusi}

Dari penelitian yang telah dilakukan maka didapatkan karakteristik responden berdasarkan jenis kelamin lebih didominasi oleh pasien berjenis kelamin laki-laki sebesar $52.6 \%$. Sementara karakteristik responden berdasarkan usia yaitu didominasi oleh pasien yang memiliki usia 51-60 tahun sebesar $46.8 \%$.

Perbandingan pengaruh indeks massa tubuh (IMT) perokok dengan bukan perokok pada pasien penyakit jantung dapat dilihat dengan menggunakan uji Chi-Square. Sebanyak 78 pasien perokok dan 83 pasien yang tidak merokok merupakan sampel dalam penelitian ini. Berdasarkan hasil penelitian mengenai perbandingan indeks masa tubuh pasien perokok dengan bukan perokok pada pasien penyakit jantung, dapat dilihat bahwa pasien perokok didominasi oleh pasien yang memiliki indeks massa tubuh gemuk dan yang bukan perokok didominasi oleh pasien yang memiliki indeks massa tubuh normal.

Hasil analisis uji Chi-Square, Indeks massa tubuh pasien perokok penyakit jantung memiliki $p$-value $<0,03$ yang dikatakan terdapat hubungan antara indeks massa tubuh perokok dengan penyakit jantung. Hal ini karena rokok merupakan faktor resiko mayor terjadinya penyakit jantung dan Menurut penelitian Okvitasari (2016) merokok merupakan salah satu faktor risiko mayor timbulnya aterosklerosis. Hasil kuesioner tanya jawab pasien, didapatkan 51 pasien menyatakan bahwa kegiatan seharihari dapat mempengaruhi penyakit, sehingga pasien tidak banyak melakukan aktivitas yang memungkinkan dapat menimbulkan kenaikan berat badan. Hasil kuesioner tanya jawab, 20 pasien berat badan tidak mempengaruhi penyakit yang diderita, sehingga mereka tidak menjaga makanan dan berat badan.

Hasil penelitian ini didukung oleh penelitian yang dilakukan oleh Okvitasari (2016), dimana hasil penelitiannya menunjukkan berat badan yang berlebih akan mengakibatkan 2 kali risiko dari yang berbadan normal terhadap terjadinya penyakit jantung koroner Selain itu penelitian ini juga menunjukkan hasil penelitian bahwa dari pasien penyakit jantung koroner yang diteliti, sebagian besar memiliki indeks massa tubuh yang lebih dari 25 atau kelebihan berat badan yang sulit diturunkan karena memiliki kebiasaan yang buruk yaitu merokok. 
Hasil diatas berbanding terbalik dengan indeks massa tubuh pasien perokok yang memiliki $p$-value $<0,03$, pasien bukan perokok memiliki $p$-value $>0,05$, dimana tidak terdapat hubungan antara indeks massa tubuh pasien bukan perokok dengan penyakit jantung. Hal ini mungkin di sebabkan karena ada faktor resiko lain seperti adanya hipertensi sebanyak 20 pasien, diabetes melitus sebanyak 3 pasien dan kolesterol sebanyak 21 pasien. Beberapa penelitian juga membuktikan bahwa faktor lain seperti riwayat penyakit keluarga, dislipidemia, hipertensi, dan diabetes mellitus merupakan faktor yang berperan terhadap kejadian penyakit jantung koroner. Faktor risiko tersebut diperparah dengan pola hidup yang tidak sehat, seperti merokok dan kurangnya aktivitas fisik. Hasil penelitian ini didukung oleh penelitian Sutanto (2010) Hipertensi akan meningkatkan beban jantung, sehingga dinding jantung akan menebal, akibatnya jantung semakin lama semakin membesar, kondisi ini membuat kerja jantung melemah. Hipertensi bukan faktor risiko yang berdiri sendiri. Hipertensi yang disertai dengan kegemukan, merokok, kadar kolesterol yang tinggi atau penyakit kencing manis akan meningkatkan risiko serangan jantung beberapa kali (Tapan, 2005), dan Penelitian Yuliani (2014) pada pasien diabetes mellitus tipe 2 juga menunjukkan bahwa ada hubungan yang bermakna antara hipertensi dengan kejadian penyakit jantung koroner pada penderita DM tipe $2(p=0,007)$. Hasil Tanya jawab kuesioner bahwa gaya hidup tidak mempengaruhi berat badan, sehingga pasien tidak memperhatikan dan menjaga makanan yang akan menimbulkan kolesterol.

Berdasarkan hasil pembahasan yang telah diuraikan mengenai perbandingan indeks masa tubuh pasien dengan perokok bukan perokok pada pasien penyakit jantung di RSUD Kota Bekasi tahun 2016.

\section{Simpulan}

1. Indeks Massa Tubuh mempengaruhi penyakit jantung

2. Hasil penelitian menunjukkan bahwa orang yang merokok dapat memicu penyakit jantung.

3. Terdapat hubungan antara indeks massa tubuh perokok dengan penyakit jantung pada penelitian ini.

4. Berdasarkan hasil penelitian, indeks massa tubuh yang merokok memiliki indeks massa tubuh yang lebih besar. Dalam Islam indeks massa tubuh berlebih akan mengakibatkan berbagai penyakit serta, merokok termasuk perbuatan yang dapat merusak diri atau membahayakan diri sendiri yang dapat memicu terjadinya penyakit jantung. Islam juga tidak memperbolehkan umatnya untuk membahayakan diri sendiri dan orang lain.

\section{Saran}

Berdasarkan pengalaman saat melakukan penelitian dan analisa terhadap hasil penelitian, peneliti memberikan saran sebagai berikut;

1. Kepada Pasien Penyakit Jantung Melakukan pengaturan pola makan atau menjaga makan seimbang agar terhindar dari kelebihan berat badan yang akan menimbulkan banyak penyakit dan komplikasi. Melakukan aktivitas yang dapat menyehatkan jantung seperti olahraga.

2. Kepada Peneliti Selanjutnya Bagi peneliti selanjutnya dapat melakukan penelitian kembali dengan variabel yang lebih lengkap dan berbeda dilihat dari 
berbagai faktor yang lebih dominan mempengaruhi penyakit jantung.

\section{Daftar Pustaka}

Damanik, Harusn Alrasyid. 2009. Potensi Tempe Kedelai dalam Terapi Nutrisi Medik Pada Obesitas Dewasa Dengan Komorbid. Pidato Pengukuhan Jabatan Guru Besar Tetap. Universitas Sumatra Utara. Sumatra.

Leffondre, K., Abrahamowicz, M., Siemiatycki, J., Rachet, B. 2002. Modelling Smoking History: A Comparison of Different Approach. American Journal of Epidemiology.

Septawati, L. 2009. Bersahabat Dengan Penyakit Jantung. Yogyakarta: Kanisus. Sutanto.2010. Cekal (Cegah dan Tangkal) Penyakit Modern. Yogyakarta: Andi

Supriyono M. 2008. Faktor-faktor Risiko yang Berpengaruh Terhadap Kejadian Penyakit
Jantung Koroner Pada Kelompok Usia < 45 Tahun [Tesis]. Semarang: Universitas Diponegoro

Tapan E. 2005. Penyakit Degeneratif. Jakarta: PT Elex Media KomputindoT.F.M Van Berkel, H. Boersma, J.W

Roos-Hesselink, R.A.M Erdman and M.L Simoons, 1999. Impact of smoking cessation and smoking interventions in patient with coronary heart disease, Departement of Cardiology, Departement of Medical Psychology and Psychotherapy, Heartcentre, Rotterdam, The Netherlands, 1999, 20: 1773-1782.

Yuliani F, Oenzil F, Iryani D. Hubungan Berbagai Faktor Risiko Terhadap Kejadian Penyakit jantung Koroner pada Penderita Diabetes Mellitus tipe-2.Jurnal Kesehatan Andalas. 2014. 